\title{
Senduro Goat Semen Characteristics as A Candidate for Low Temperature Storage
}

\author{
Nur Ducha*, Widowati Budijastuti, and Dwi Anggorowati Rahayu \\ Biology Department, Universitas Negeri Surabaya
}

\begin{abstract}
The goal of this study was to investigate the reproductive profile of male Senduro Goats as superior male candidates based on data of semen quality. The experiment was carried out on ten male Senduro Goats kept at the Singosari Animal Husbandry Service Unit in East Java, Indonesia. An artificial vagina was used to collect sperm. The macroscopic and microscopic qualities of fresh Senduro Goat sperm have been observed. Color, volume, smell, $\mathrm{pH}$, and viscosity were examples of macroscopic observations. Concentration, motility, viability, and membrane integrity were examples of microscopic observations. The results of macroscopic observations showed that the average of Senduro Goat semen was milky white; with volume $1,24 \pm 0,22 ; 6.77 \pm 0.05$; thick semen. The results of microscopic observations showed that there was concentration $2,5 \times 109 \pm 0.1$; mass motility +++ ; individual motility $77.5 \% \pm 2.63$; viability $88.98 \% \pm$ 2.07; membrane integrity $89.71 \pm 1.69$. Based on the results of these studies, it can be concluded that the semen of Senduro Goat has good quality so it can be processed further, namely storage at low temperatures and applied to Artificial Insemination technology.
\end{abstract}

Keywords: Senduro Goats, Artificial Insemination technology, low temperatures Storage

\section{Introduction}

The Senduro Goat is one of the Indonesian Local Goats autorized by the Indonesian Ministry of Agriculture (1), and is a cross between the Peanut Goat and the Jamnapari Goat. Senduro goats have two advantages: they produce meat and milk (2). The Senduro Goat's superiority must be maintained by increasing its population. Artificial insemination can be used to help increase the population of livestock. Artificial Insemination is easier to implement when the sperm has been diluted and stored at a low temperature, either at 4$5^{\circ} \mathrm{C}$ or frozen.

Several factors influence the success of Artificial Insemination, including diluent composition, freezing method, quality and integrity of spermatozoa membranes for fertilization ability, insemination method, insemination method, and insemination dose (3). The ability to fertilize is directly related to the quality of the spermatozoa. When Artificial Insemination is performed, post-stored spermatozoa at low temperatures, both at freezing temperatures and at 4-5 C, must be of good quality for successful fertilization. As a result, good fresh semen must be diluted with diluent media and stored at low temperatures before Artificial Insemination can actually occur.
Before dilution and storage at low temperatures, fresh semen should be evaluated, which includes macroscopic and microscopic observations (4). The quality of spermatozoa decreases after 72 hours of fresh semen collection, which causes a decrease in fertilization ability (5). As a result, the quality of fresh sperm must be good, particularly the motility and viability of spermatozoa prior to dilution and storage at low temperatures. According to the findings of Dorado et al. (6), the motility of spermatozoa from the evaluation of fresh sperm was the best predictor of test results after low-temperature storage.

The quality fresh semen profile of Senduro Goat has not been widely reported. The goal of this study was to examine the macroscopic and microscopic quality of the Senduro Goat's sperm, as well as to relate the macroscopic and microscopic qualities. The findings of this study are significant in determining whether the fresh semen of the Senduro Goat is suitable for storage at low temperatures or freezing as one of the steps performed prior to the application of Artificial Insemination.

\footnotetext{
* Corresponding author : nurducha@unesa.ac.id
} 


\section{Materials and Methods}

\subsection{Fresh Semen Collection}

Fresh sperm was collected from 10 male Senduro Goats kept in the Technical Implementation Unit of the Animal Husbandry Service, Singosari, Malang, East Java, in accordance with Indonesian goat rearing standards (7). An artificial vagina was used to collect fresh sperm.

\subsection{Macroscopic Observation}

Macroscopic and microscopic examinations of fresh sperm quality are performed. Volume, color, smell, $\mathrm{pH}$, and viscosity are examples of macroscopic quality parameters. Microscopic quality parameters include locomotion or motility (including mass motility and individual motility), viability, normal morphology, and spermatozoa membrane integrity.

Macroscopic testing or physical parameters, such as volume, are measured with a measuring tube / cup; the color of the semen is observed directly with the eye. After liquefaction, semen viscosity was measured using a glass rod dipped in semen to measure the length of the semen thread; $\mathrm{pH}$ was measured using $\mathrm{pH}$ paper (8) (9).

\subsection{Microscopic Observation}

\subsubsection{Spermatozoa motility}

A microscope was used to perform microscopic testing on motility, viability, normal morphology, and the integrity of spermatozoa membranes. Individual motility was observed as well as mass motility. Dripping semen on a slide and observing the forward movement under a microscope with a weak magnification (100X) at $37^{\circ} \mathrm{C}$ was used to test mass motility. The joint movement of the spermatozoa population in the form of waves is viewed as the mass movement (8). Individual motility was observed by dripping semen on a slide and then viewing it under a microscope at $200 \mathrm{X}$ magnification at $37^{\circ} \mathrm{C}$. The number of spermatozoa observed was calculated.

\subsubsection{Spermatozoa viability}

The viability (spermatozoa viability) was determined by dripping semen on a glass slide, mixing it with a drop of eosin negrosin dye, preparing a smear, and observing it under a microscope at $200 \mathrm{X}$ magnification. Spermatozoa that are still alive have colourless heads, whereas dead spermatozoa have purple heads. The viability of spermatozoa was observed as a percentage.

\subsubsection{Membrane spermatozoa integrity}

Observation of spermatozoa membrane integrity using a hypoosmotic solution test, consisting of $0.31 \mathrm{~g}$ Sodium Citrate mixed with $0.565 \mathrm{~g}$ Fructose in $50 \mathrm{ml}$ Aquades (10),(11). $100 \mathrm{~L}$ of fresh Senduro Goat semen was mixed with $1000 \mathrm{~L}$ of hypoosmotic solution, which was then incubated at $37 \mathrm{C}$ for 30 minutes before $0.2 \mathrm{~mL}$ of the mixture was taken, dripped onto an object glass, and examined under a $400 \mathrm{X}$ magnification microscope. Spermatozoa with swollen or coiled tails were counted, and up to 200 spermatozoa were assigned at random.

\section{Results and Discussion}

The macroscopic and microscopic observations of Senduro Goat fresh semen profile include macroscopic and microscopic observations. Table 1 shows the results of macroscopic observations.

Table 1. Macroscopic Characteristics of Senduro Goat Semen

\begin{tabular}{ll}
\hline Parameter & Mean \pm SD \\
\hline Volume & $1,24 \pm 0,22$ \\
pH & $6,77 \pm 0,05$ \\
Color & Milky White \\
Consistency & Viscous \\
\hline
\end{tabular}

Based on the results of macroscopic observations, it showed that the semen of the Senduro Goat was normal. Based on observations, it was shown that the quality of fresh semen was macroscopically normal, both in terms of volume, color, $\mathrm{pH}$, and viscosity parameters. Goat semen is said to be normal Hafez (12) if it shows the following characteristics: yellowish white / milky white color, $\mathrm{pH}$ ranges from 6,5 to 7,8 ; volume ranges from 0,3 to $2,0 \mathrm{ml}$. The viscosity of semen is influenced by the concentration of spermatozoa. The higher the concentration of spermatozoa, the semen will be more viscous. The volume of fresh semen can be influenced by the age of the animal/livestock, frequency of storage, and animal health factors. According to [13], the color of semen is usually yellowish white, usually due to the presence of riboflavin, the color of semen becomes red if it is contaminated with blood.

Microscopic observations were carried out using a microscope. The results of microscopic observations of Senduro Goat semen can be seen in Table 2 below.

Table 2. Microscopic Characteristics of Senduro Goat Semen

\begin{tabular}{ll}
\hline Parameter & Mean \pm SD \\
\hline Spermatozoa consentration & $2,5 \times 10^{9} \pm 0,1$ \\
Mass movement & +++ \\
Individu motility (\%) & $77,5 \pm 2,63$ \\
Viability (\%) & $88,98 \pm 2,07$ \\
Membrane integrity (\%) & $89,71 \pm 1,69$ \\
\hline
\end{tabular}

Based on the results of microscopic observations in Table 2 was showed that the concentration of spermatozoa in the fresh semen of the Senduro Goat was high. This result is similar to the study (14) Aguiar et el. A high concentration of spermatozoa will have the opportunity to be diluted with diluent media and then the cooling process is carried out at low temperatures.

Based on the results of microscopic observations in Table 2 shows good mass movement data. The +++ sign 
indicates that the mass movement is very fast, with illustrations such as the rapid movement of clouds. The results showed that most of the mass movement in fresh semen was very fast and simultaneous. These results are similar to the results of the study (15) Armanshah et al. on Peanut Goat. Fast and simultaneous mass movement indicates that the motility of spermatozoa was good. According to (12) Hafez, the normal mass movement was between $2+$ and 3+. Baes on David (16) research results showed that good mass motility is closely related to the ability of spermatozoa fertility. While the results of the study (17) Argiris et al. showed that the mass movement of spermatozoa is related to the age of the animal. At the age of sexual immaturity (reproduction), mass movement is still low $(1+)$, as well as in old age.

The results of the spermatozoa motility observation were obtained a high average percentage $(77,5 \pm 2,63)$. The data was almost the same as the study conducted by (18) Chlander et al., and (14) Aguiar et el. Spermatozoa motility is individual motility measured in percent, which is based on spermatozoa moving straight ahead compared to the overall spermatozoa population (moving straight ahead quickly, moving straight ahead but slowly, moving in circles, moving in place, not moving/quite). Spermatozoa that move straight ahead and fast are called progressive motility. The motility of spermatozoa from fresh semen can be influenced by the physiological conditions of the animal. The results of the study (17) Argiris et al showed that the age factor can affect the motility of spermatozoa, animals that are still young, not yet reproductively mature, show lower motility results compared to mature reproductive age.

The results of viability observations (spermatozoa viability showed a high percentage). This was in accordance with (12) Hafez, said that the percentage of live spermatozoa in fresh goat semen ranged from $65-$ $85 \%$. The results of membrane integrity observations showed a high percentage. Spermatozoa membrane integrity in good fresh semen ranges from $80-90 \%$. The integrity of the plasma membrane is a major determining factor for the maintenance of fertility. Acrosomal capacitation and reactions are essential physiological reactions processes that sperm must achieve to achieve fertilization. There is a need for assays that analyze the membrane integrity of spermatozoa. Under normal osmotic conditions, there will be no shrinkage and swelling of spermatozoa. The other research showed (19) under hypoosmotic conditions, fluid transport occurs into cells that have an intact membrane between the outside and inside of the cell. The cell will swell or tail bend will occur due to the influx of fluid. A higher percentage rate of hypo-osmotic swelling indicates that the semen has a higher fertility rate. Hypoosmotic swelling is directly proportional to the freezability of semen.

Overall data on semen quality, both macroscopic and microscopic, were showed in good results, this were probably because nutrition and maintenance management factors were met properly, so that the body growth was in line with the growth of the reproductive system. Good quality semen can be further processed for storage at low temperatures and applied to Artificial Insemination technology. However, based on research of Aquiar et al (14) was found that semen obtained from goats kept in the wet season in better quality after storage at low temperatures, compared to that kept in the dry season. Environmental factors rearing with hot temperatures can affect the seminiferous tubules, and affect the quality of spermatozoa.

\section{Conclusion}

Based on the results of the study, macroscopic observations were included volume, color, $\mathrm{pH}$, and viscosity showed good results in the normal category. The results of microscopic observations which were included in concentration, mass motility, individual motility, viability, and membrane integrity of spermatozoa showed good and normal results. It can be concluded that the quality of Senduro Goat semen can be a candidate for the storage process at low temperatures and subsequently to be applied to Artificial Insemination technology.

This research was funded by Universitas Negeri Surabaya, through the Basic Research Grant project. The researcher would like to thank for Rector of Universitas Negeri Surabaya, and the Chair of the Research and Service Institute for providing the opportunity for researchers to carry out this research. The researcher also thanks the Head of Animal Husbandry East Java for the permission to carry out the research.

\section{References}

1. Minister of Agriculture Republic of Indonesia. 2014. SK No 1055/Kpts/SR.120/10/2014 The decision of goat breed Senduro (Jakarta: Minister of Agriculture Republic of Indonesia)

2. T.E. Susilorini, A Furqon, A Ridhowi, A Murthadho, ND Putra, and J Palayakun. 2020. Phenotypic characteristic of Doe Senduro Goat in senduro sub district, Lumajang regency. IOP Conf. Series: Earth and Environmental Science $\mathbf{4 7 8}$ (2020) 012092. Scopus indexed.

3. A Kowalczyk, E. C. Piatkowska, and M. Kuczaj. 2019. Factors Influencing the Popularity of Artificial Insemination of Mares in Europe. Journal Animals, 9, 460; doi:10.3390/ani9070460

4. E. Lukaszewicz and W. Kruszynski. 2003. Evaluation of fresh and frozen-thawad semen of individual ganders by assesment of spermatozoa motility and morphology. Theriogenology 59: 1627-1640, (2003).

5. L.O'Hara, J.P.Hanrahan, L.Richardson, A.Donovan, S.Fair, A.C.O. Evans, P.Lonergan. 2010. Effect of storage duration, storage temperature, and diluent on the viability and fertility of fresh ram sperm. Theriogenology (73): 4. 541-549.

6. J.Dorado M. Hidalgo A.Muñoz, I.Rodríguez. 2009. Assessment of goat semen freezability according to the spermatozoa characteristics from fresh and 
frozen samples. Animal Reproduction Science (112): 1-2, 150-157.

7. Minister of Agriculture Republic of Indonesia. Goat and sheep breeding guidelines. (Jakarta: Minister of Agriculture Republic of Indonesia). (2014).

8. K. Vijayalakshmy 1, M. Virmani, D. Kumar, P. Kumar, and H. Rahman. Different methods of assessing semen quality. Indian Farmer 5(12): 1383-1387, (2018).

9. Hafez and E.S.E Hafez. Reproduction in Farm Animals. $7^{\text {th }}$ eds. Lippincott Williams \& Wilkins. Baltimore, Marryland, (2008).

10. J.F. Fonseca1,3, C.A.A. Torres2 , V.V. Maffili2 , A.M. Borges2 , A.D.F. Santos2 , M. T. Rodrigues2 , R.F.M. Oliveira2. The hypoosmotic swelling test in fresh goat spermatozoa. Anim. Reprod., v.2, n.2, p.139-144, (2005).

11. Pacheco JI,1 Mamani Cato RH,2 Vélez VM1. Effect of seminal plasma on hipoosmotic swelling test in fresh alpaca spermatozoa. MOJ Biol Med. 2017;2(4):291-292, (2017).

12. Hafez E.S.E. 2008. Preservation and Cryopreservation of Gamete and Embryos, In Reproduction in Farm Animals. 7 th eds. B. Hafez and E.S.E Hafez. Lippincott Williams \& Wilkins. Baltimore, Marryland. USA, (2008).

13. Ax R.L., Dally M., Didion B.A., Lenz R.W., Love C.C., Varner D.D., Hafez B., and Bellin M.E. 2008. Semen Evaluation, in Reproduction in Farm Animals. $7^{\text {th }}$ eds. B. Hafez and E.S.E Hafez. Lippincott Williams \& Wilkins. Baltimore, Marryland. USA, (2008).

14. G.V. Aguiar1, M.F. van Tilburg1, A.G.V. Catunda1, C.K.S. Celes1, I.C.S. Lima1, A.C.N. Campos1, A.A.A. Moura1* , A.A. Araújo2. Sperm parameters and biochemical components of goat seminal plasma in the rainy and dry seasons in the Brazilian Northeast: the season's influence on the cooling of semen. Arq. Bras. Med. Vet. Zootec., v.65, n.1, p.6-12, (2013).

15. T. Armansyah, E. R. P. Barat, C. V. R. Handini, D. Aliza, A. Sutriana, H. Hamdan, B. Panjaitan, A. Sayuti and T. N. Siregar. Concentration and motility of spermatozoa and testosterone level of kacang goat after seminal vesicle extract administration. Open Veterinary Journal, Vol. 8(4): 406-410, (2018).

16. I. David, P. Kohnke, G. Lagriffoul, O. Praudf, F. Plouarbouéf, P. Degondg, X. Druart. Mass sperm motility is associated with fertility in sheep. Animal Reproduction Science. 161: 75-81, (2015).

17. A. Argiris, Y.S. Ondo, S.I. Santoso, and E. Kurnianto. Effect of age and bulls of fresh semen quality and frozen semen production of Holstein Bulls in Indonesia. IOP Conf. Series: Earth and Environmental Science 119, 012033, (2018).

18. J. E. Chandler, C. L. Painter, R. W. Adkison, M. A. Memon, and P. G. Hoyt. Semen Quality Characteristics of Dairy Goats. J Dairy Sci 71:1638-1646, (1988).
19. W. M. M. Nalley1 and R. I. Arifiantini2. The hypoosmotic swelling test in the fresh Garut Ram Spermatozoa. J. Indonesian Trop.Anim.Agric. 38(4), (2013). 